\title{
Effect of bypass lysine, methionine and fat on growth and nutritional efficiency in growing Jaffrabadi heifers
}

\author{
A.P. Gajera, K.S. Dutta, D.K. Parsana, H.H. Savsani, M.D. Odedra, P.U. Gajbhiye, K.S. Murthy and J.A. Chavda \\ Department of Animal Nutrition \\ College of Veterinary Science and Animal Husbandry, Junagadh Agricultural University, Junagadh, Gujarat (India) \\ Corresponding author: D.K. Parsana, email: parsana_dipen@yahoo.com
}

Received: 26-05-2013, Revised: 25-06-2013, Accepted: 25-06-2013, Published online: 16-08-2013

doi: 10.14202/vetworld.2013.766-769 How to cite this article: Gajera AP, Dutta KS, Parsana DK, Savsani HH, Odedra MD, Gajbhiye PU, Murthy KS and Chavda JA (2013) Effect of bypass lysine, methionine and fat on growth and nutritional efficiency in growing Jaffrabadi heifers, Veterinary World 6(10): 766-769.

\begin{abstract}
Aim: Our objective was to evaluate the effect of bypass nutrients i.e. bypass lysine, methionine and fat on growth and nutritional efficiency in growing Jaffrabadi buffalo heifers aged 21 to 27 months.

Materials and Methods: Twenty buffalo heifers were divided into four groups of equal number: control group (T1), bypass fat supplementation (T2), bypass lysine and methionine supplementation (T3) and bypass lysine, methionine and fat supplementation (T4). The feeds were analyzed for proximate constituents. Body measurements (body length, body height, heart girth, body girth, pelvic length and pelvic width) as well as body weights (kg) of individual animals were recorded at the beginning and thereafter at every fifteen day interval throughout the experimental period. Feed conversion ratio was determined in terms of dry matter required per kg gain in body weight under different treatments.
\end{abstract}

Results: The total weight gain and average daily body weight gain during the experiment was highest in T4 followed by T2, which differed significantly $(\mathrm{P}<0.05)$ from that of $\mathrm{T} 1$. Biometric changes were uniform in all the experimental groups and the changes were positive. Heifers under the present experimental condition, gained biometry considerably though not significantly. Treatment differences were significant $(\mathrm{P}<0.05)$ for average value of percent dry matter intake but no significant differences were found between treatments for average daily dry matter intake and dry matter intake per kg metabolic body weight. The efficiency of feed utilization was best in T4 followed by T2, T3 and T1 groups but the treatment differences were statistically non significant $(\mathrm{P}>0.05)$.

Conclusion: Incorporation of bypass nutrients (lysine, methionine and fat) in the ration of growing Jaffrabadi heifers improved live weight gain, dry matter intake ( $\mathrm{kg} /$ day), dry matter intake per $\mathrm{kg}$ metabolic weight and feed conversion ratio (DMI/kg body weight gain).

Keywords: biometry, bypass nutrients, dry matter intake, growth, nutritional efficiency

\section{Introduction}

India is the highest milk producing nation in the world and aims at producing 172 MMT milk at an annual growth rate of 4 percent by the year 2022 [1]. Llysine is a necessary building block for all $\mathrm{s}$ in the body and plays a major role in calcium absorption; building muscle protein; recovering from surgery or sports injuries; and the production of hormones, enzymes, and antibodies. Methionine is one of the two sulfurcontaining proteinogenic amino acids. Its derivative Sadenosyl methionine (SAM) serves as a methyl donor during transmethylation reactions. Methionine is also an intermediate in the biosynthesis of cysteine, carnitine, taurine, lecithin and other phospholipids.

Protein is the first limiting nutrient in India especially because the bovines are fed poor quality roughages that are low in protein and protein's availability being only 19-20 MMT against the requirement of 30 to $35 \mathrm{MMT}$ [2]. Additionally, depending on the nature and source of the protein supplement, 60 to $70 \%$ of

Copyright: The authors. This article is an open access article licensed under the terms of the Creative Commons Attribution License (http://creativecommons.org/licenses/by/2.0) which permits unrestricted use, distribution and reproduction in any medium, provided the work is properly cited. protein is degraded in the rumen by ruminal microbes with the production of microbial protein which leads to degrading of high quality protein and as a result the availability of original amino acid sequence does not fully remain assured [3].

Another important by-pass nutrient is the by-pass fat which is the most energy dense nutrient available. Besides, it can also overcome the deleterious effect of fats having a low melting point on fibre digestibility, feed intake and absorption of magnesium and calcium. Bypass fat helps in overcoming this negative energy balance phenomenon.

In a typical diet for high yeilding bovines, approximately $40 \%$ of the protein consumed must be true protein that escapes degradation, whereas $60 \%$ of the protein can be a mixture of protein and non-protein nitrogen that is degraded and incorporated into the rumen microbes [4]. Improved growth performance through feeding rumen by-pass Methionine and Lysine in young Jaffrabadi heifers (12-15 months in age) has been reported by others [5].

In order to achieve the target of milk production, fast and adequate growth of heifers as replacement herd is highly essential. Due to a severe shortage in 
Table-1. Percent average composition of feed and fodder (on DM basis) fed to the experimental heifers

\begin{tabular}{lcccc}
\hline & Concentrate & Jowar & MetiPEARL & LysiPEARL \\
\hline DM & 94.85 & 45 & - & - \\
OM & 82.18 & 92.18 & - & - \\
CP & 21.00 & 4.12 & - & - \\
CF & 13.20 & 28.00 & - & - \\
EE & 3.5 & 1.50 & - & - \\
NFE & 40.13 & 56.69 & - & - \\
TA & 17.82 & 7.82 & - & - \\
Silica & 6.12 & 3.26 & - & - \\
Methionine & - & - & 45 & - \\
Lysine & - & - & - & - \\
\hline
\end{tabular}

DM- Dry matter, OM-Organic matter, CP-Crude protein, CF- Crude fibre, EE- Ether extract, NFE- Nitrogen free extract, TA- Total ash

their availability, available feeds and fodders necessitate very judicious utilization. One of the various available technologies that could help in judicious utilization of available feed resources and thus could minimize the gap between their requirement and availability is the use of rumen bypass nutrients such as bypass protein and more importantly, bypass limiting amino acids like bypass methionine and bypass lysine along with bypass fat.

Realizing the potential and advantages of rumen by-pass methionine, lysine as well as the rumen bypass fat the present investigation has been carried out to determine the effect of bypass nutrients i.e. bypass lysine, methionine and fat on growth and nutritional efficiency in growing Jaffrabadi buffalo heifers.

\section{Materials and Methods}

The study was approved by the committee formed for the research by the university authorities and was conducted from $8^{\text {th }}$ September, 2012 to $21^{\text {st }}$ December, 2012. Twenty Jaffrabadi buffalo heifers aged 21 to 27 months were included in our experiment that was conducted at the Cattle Breeding Farm, Junagadh Agricultural University, Junagadh. These animals were divided into four groups of five each. T1 (Control group) was fed with $15 \mathrm{Kg}$ seasonal greens + concentrate to meet DCP requirement, as per the NRC guidelines [6]. T2 was fed similar to T1 + rumen bypass fat @100 g/ head / day, T3 was fed similar to T1+ bypass lysine and methionine@15 and 5g/head / day and T4 was fed similar to T1 along with feeding bypass lysine and methionine (as in T3) and also bypass fat (as in T2). Experimental ingredients were purchased from Kemin Industries South Asia Pvt. Ltd.

The feeds were thoroughly analyzed for proximate constituents (Table-1) using the methods described earlier [7]. For body measurements: body length, body height, heart girth, body girth, pelvic length and pelvic width of individual animals were recorded (Table 2 ) for two consecutive days, before feeding and watering at the beginning of the experiment and thereafter at every fifteen day interval throughout the experimental period. Body weight (in $\mathrm{kg}$ ) of heifers was recorded (Table-2) at the beginning of the experiment and thereafter at fifteen day intervals during the experimental period. On the basis of feed and fodder consumption, dry matter (DM) consumed by the animals was calculated. Feed conversion ratio was determined in terms of DM required per $\mathrm{kg}$ gain in body weight under different treatments (Table-3).

Statistical analysis: The data were analyzed statistically using a Complete Randomized Design (CRD) as per the methods described in Snedecor and Cochran [8] and a significance was declared when the $P$ value was less than 0.05 .

\section{Results and Discussion}

Table-2 shows the data of body weight and biometric changes while Table- 3 shows the data of dry matter intake and feed conversion efficiency of experimental Jaffrabadi heifers.

Body weight: The total weight gain $(\mathrm{kg})$ and average daily body weight gain (g) during the experiment was highest in bypass methionine, lysine and fat supplemented group (T4) followed by fat supplemented group (T2), which differed significantly $(\mathrm{P}<0.05)$ from that of control group $(\mathrm{T} 1)$.

Body weight gain values of Jaffrabadi heifers reported in the present study are in agreement with that reported by several scientists in steers [9], in murrah heifers [10] and by other scientists who evaluated the effects of incorporation of rumen protected lysine and methionine on growth in Jaffrabadi heifers $[11,12]$. Our results revealed that there were significant $(\mathrm{P}<0.001)$ improvement in average weight gains in the buffalo heifers of the bypass nutrients fed group compared to those of control concentrate fed group.

Biometry: Differences in respect of initial biometry as well as gain in biometry in heifers of different groups during the experimental period were non-significant (Table-2).

Similar findings have been reported in experiments with Jaffrabadi heifers [11,12] and growing Murrah buffalo calves [13]. However, when animal growth tends to adult from heifer, simply height at wither will be increase. [14]. Significant $(\mathrm{P}<0.05)$ effect of feeding formaldehyde treated rapeseed meal on heart girth but not on body length and height was reported [15]. The same trend $(\mathrm{P}<0.01)$ was also reported in respect of heart girth [16].

Dry matter intake: Dry matter intake in case of average daily dry matter intake (DMI) and dry matter intake per kg metabolic body weight were statistically nonsignificant $(\mathrm{P}>0.05)$ though, treatment differences 
Table-2. Body weight and biometric changes of experimental heifers $(n=5)$.

\begin{tabular}{|c|c|c|c|c|c|c|}
\hline Treatments & T1 & T2 & T3 & T4 & SEM \pm & C.D.at $5 \%$ \\
\hline \multicolumn{7}{|c|}{ Average body weight $(\mathrm{kg})$ at 15 day interval } \\
\hline $\mathrm{PO}$ & $366.80 \pm 21.06$ & $364.00 \pm 22.03$ & $366.80 \pm 23.00$ & $371.00 \pm 19.30 \pm 19.30$ & 19.13 & NS \\
\hline P7 & $442.80 \pm 18.73$ & $456.40 \pm 23.78$ & $455.20 \pm 24.71$ & $470.80 \pm 18.52$ & 19.34 & NS \\
\hline Changes & $76.00 \mathrm{~b} \pm 3.76$ & $92.40 \mathrm{a} \pm 4.92$ & $88.40 a b \pm 7.91$ & $99.80 \mathrm{a} \pm 3.42$ & 4.74 & 14.23 \\
\hline \multicolumn{7}{|c|}{ Average daily body weight gain $(\mathrm{g})$} \\
\hline P1 & $693.33 \pm 76.74$ & $880.00 \pm 121.11$ & $746.67 \pm 86.28$ & $933.33 \pm 124.72$ & 93.33 & NS \\
\hline P7 & $733.33 \pm 117.33$ & $826.67 \pm 76.74$ & $760.00 \pm 98.88$ & $1000.0 \pm 214.74$ & 123.01 & NS \\
\hline Average & $723.81 \mathrm{~b} \pm 35.79$ & $880.00 a \pm 46.85$ & $841.90 a b \pm 75.34$ & $950.48 a \pm 32.54$ & 45.19 & 135.48 \\
\hline \multicolumn{7}{|c|}{ Average heart girth $(\mathrm{cm})$} \\
\hline $\mathrm{PO}$ & $173.40 \pm 4.08$ & $173.80 \pm 2.96$ & $176.80 \pm 3.38$ & $178.60 \pm 3.59$ & 3.15 & NS \\
\hline P7 & $184.20 \pm 3.64$ & $187.20 \pm 3.48$ & $188.60 \pm 3.43$ & $191.80 \pm 3.22$ & 3.09 & NS \\
\hline Changes & $10.80 \pm 1.24$ & $13.40 \pm 1.44$ & $11.80 \pm 1.14$ & $13.20 \pm 0.65$ & 1.03 & NS \\
\hline \multicolumn{7}{|c|}{ Average body girth $(\mathrm{cm})$} \\
\hline $\mathrm{PO}$ & $184.20 \pm 3.58$ & $184.40 \pm 2.97$ & $184.40 \pm 3.78$ & $187.20 \pm 2.38$ & 2.88 & NS \\
\hline P7 & $196.80 \pm 4.35$ & $198.40 \pm 4.49$ & $197.80 \pm 4.16$ & $201.80 \pm 2.84$ & 3.59 & NS \\
\hline Changes & $12.60 \pm 1.52$ & $14.00 \pm 1.77$ & $13.00 \pm 0.71$ & $14.60 \pm 0.76$ & 1.14 & NS \\
\hline \multicolumn{7}{|c|}{ Average Body length (cm) } \\
\hline PO & $142.80 \pm 2.16$ & $141.80 \pm 1.34$ & $140.80 \pm 2.04$ & $144.00 \pm 1.45$ & 1.60 & NS \\
\hline P7 & $152.80 \pm 2.53$ & $152.80 \pm 1.51$ & $153.00 \pm 3.00$ & $156.60 \pm 1.68$ & 2.03 & NS \\
\hline Changes & $10.00 \pm 0.93$ & $11.00 \pm 0.61$ & $12.20 \pm 1.19$ & $12.60 \pm 0.91$ & 0.83 & NS \\
\hline \multicolumn{7}{|c|}{ Average height at withers $(\mathrm{cm})$} \\
\hline $\mathrm{PO}$ & $137.00 \pm 0.61$ & $136.00 \pm 1.27$ & $134.80 \pm 2.04$ & $135.20 \pm 2.32$ & 1.52 & NS \\
\hline P7 & $141.60 \pm 0.75$ & $141.00 \pm 1.36$ & $140.60 \pm 2.56$ & $141.20 \pm 2.60$ & 1.78 & NS \\
\hline Changes & $4.60 \pm 0.27$ & $5.00 \pm 0.35$ & $5.80 \pm 0.74$ & $6.00 \pm 0.35$ & 0.41 & NS \\
\hline \multicolumn{7}{|c|}{ Average pelvic length $(\mathrm{cm})$} \\
\hline PO & $49.40 \pm 0.76$ & $49.20 \pm 0.96$ & $49.20 \pm 0.74$ & $48.00 \pm 1.22$ & 0.84 & NS \\
\hline P7 & $54.40 \pm 1.15$ & $54.60 \pm 1.09$ & $55.40 \pm 1.04$ & $54.40 \pm 1.35$ & 1.04 & NS \\
\hline Changes & $5.00 \pm 0.50$ & $5.40 \pm 0.27$ & $6.20 \pm 0.42$ & $6.40 \pm 0.27$ & 0.34 & NS \\
\hline \multicolumn{7}{|c|}{ Average pelvic width $(\mathrm{cm})$} \\
\hline $\mathrm{PO}$ & $48.00 \pm 0.71$ & $47.40 \pm 1.56$ & $48.40 \pm 0.97$ & $46.80 \pm 1.88$ & 1.22 & NS \\
\hline P7 & $53.60 \pm 0.91$ & $53.60 \pm 1.68$ & $54.00 \pm 0.93$ & $53.20 \pm 1.81$ & 1.25 & NS \\
\hline Changes & $5.60 \pm 0.27$ & $6.20 \pm 0.22$ & $5.60 \pm 0.27$ & $6.40 \pm 0.27$ & 0.23 & NS \\
\hline
\end{tabular}

* Averages in the same row with different superscripts indicate a significant $(\mathrm{P}<0.05)$ difference.

SEM-Standard error of mean, C.D.- Critical difference, PO - Initial values at begining of the experiment,

P1 - Values at the end of first fifteen days and P7 - Final values at the end of the experiment, NS-non significant

Table-3. Dry matter intake and feed conversion efficiency of experimental heifers $(n=5)$.

\begin{tabular}{lllll}
\hline Treatments & DMI kg/d & DMI kg/100 kg B.Wt. & DMI g / kg W $\mathbf{~}^{0.75}$ & FCR \\
\hline T1 & $9.86 \pm 0.44$ & $2.41 \mathrm{a} \pm 0.02$ & $98.65 \pm 4.35$ & $14.36 \pm 1.33$ \\
T2 & $9.90 \pm 0.48$ & $2.37 \mathrm{bc} \pm 0.01$ & $98.98 \pm 4.81$ & $11.94 \pm 0.65$ \\
T3 & $9.99 \pm 0.58$ & $2.39 \mathrm{ab} \pm 0.01$ & $99.85 \pm 5.84$ & $12.71 \pm 1.23$ \\
T4 & $10.10 \pm 0.40$ & $2.35 \mathrm{c} \pm 0.01$ & $100.99 \pm 4.02$ & $11.59 \pm 0.69$ \\
SEM & 0.43 & 0.01 & 4.30 & 0.91 \\
C.D. at 5\% & NS & 0.04 & NS & NS \\
\hline
\end{tabular}

* All the values are average of 105 days. DMI- Dry matter intake, FCR- Feed conversion ratio, B.Wt.-Body weight, $\mathrm{W}^{0.75}-$ Metabolic weight, SEMStanderd error of means, C.D.- Critical difference

were significant $(\mathrm{P}<0.05)$ in case of average value of percent dry matter intake.

Non significant effect was observed on DMI of protein sources rich in aminoacids [13] and similar findings were reported with calcium salt of soya acid oil fatty acids in buffalo calves [17]. However, there was significant difference in DMI in buffalo calves [18] and buffalo heifers [16], supplemented with methionine and lysine.

Feed conversion ratio: Feed conversion ratio was calculated as dry matter required per kg of body weight gain. The efficiency of feed utilization was highest in T4 followed by T2, T3 and T1 but the treatment differences were statistically non significant $(\mathrm{P}>0.05)$.

These findings are in agreement with results obtained in studies that evaluated the effect of rumen protected Lysine and Methionine in Jaffrabadi heifers [12]. Contrary to present findings, the effect of bypass fat supplementation on growth and nutrient utilization in calves reported improved feed conversion ratio
( $\mathrm{P}<0.05$ ) by $20.70 \%$ in treatment group over that of control [19]. Similarly, significant reduction in DM intake $(\mathrm{kg} / \mathrm{kg}$ gain) in Surti buffalo heifers fed with different levels $(0,30$ and 60 parts) of cotton seed in concentrate mixture [20]. Significant effect was reported in DM intake $\mathrm{kg} / \mathrm{kg}$ gain (8.52 vs. 11.37) in crossbred calves fed with concentrate mixture containing a RDP:UDP ratio of 65:35 than that of calves fed with concentrate mixture having a RDP:UDP ratio of 55:45 [21].

\section{Conclusion}

The supplementation of rumen bypass nutrients (bypass methionine, lysine and fat) in the ration of Jaffrabadi heifers significantly $(\mathrm{P}<0.05)$ improved their live weight gain, dry matter intake (kg/day), dry matter intake per $\mathrm{kg}$ metabolic weight and feed conversion ratio (DMI $/ \mathrm{kg}$ body weight gain).

\section{Authors' contributions}

APG carried out experiment. DKP, JAC and MDO did 
the sampling and laboratory works. PUG did the statistical analysis. HHS and KSM drafted the manuscript and critically reviewed the manuscript. KSD designed and approved the study plan. All authors read and approved the final manuscript.

\section{Acknowledgements}

Authors would like to thank Dr. P. U. Gajbhiye, Research Scientist, Cattle Breeding Farm for supporting us and for providing the required facilities as well as financial support to conduct this experiment. We are also thankful to Dr. P. H. Vataliya, Principal and Dean, Veterinary College, JAU, Junagadh, for help during the entire study.

\section{Competing interests}

The authors declare that they have no competing interests.

\section{References}

1. Kayastha, T.B. and Dutta, S. (2012) A Few Nutritional updates for feeding dairy animals. Livestock Line, p.14-17.

2. Haque, $\mathrm{N}$ and Hossain, A. (2012) Concepts of Bypass Protein Feeding in Ruminants. Livestock Line, p: 9-13.

3. Gulati, S. K., Ryde, I., Kaur, R., Scott, T. W., Garg, M. R., Serasia, P. L. and Singh, D. K. (2001) Role of protected nutrients in sustainable milk production. In proc. $\mathrm{X}$ animal nutrition conference. Karnal, India.

4. Taquire, N. A., Shahzad, M. A., Nisa, M., Sarwar, M. and Fayyaz, M. (2010) Influence of bypass protein on Buffalo productivity. Proceedings 9th world buffalo congress. New Delhi, India.

5. Movaliya, J. K. (2012) Effect of rumen bypass methionone and lysine supplementation on performance of Jaffrabadi heifers. M.V.Sc. thesis submitted to Junagadh Agricultural University, Junagadh, India.

6. NRC. (2001) Nutrient Requirement of Dairy Cattle. 6th and 7th Eds. National Academy Press, Washington, DC.

7. AOAC. (1999) Official Method of Analysis, 18th ed., Association of Official analytical Chemists, Washington, DC.

8. Snedecor, G. W. and Cochran, W. G. (1994) Statistical Methods. 8th edn. Affiliated East-West press Pvt. Ltd., New Delhi.

9. Qiang, Y., Qi-yu, D., Yan, T., Nai-feng, Z., Jian-hong, W. and Meng, Z. (2011) Effects of dietary lysine to methionine ratio on growth performance, nutrient digestibility and metabolism in weaned calves. Scientia Agricultura Sinica, 44(1): 133-142.
10. Vahora, S.G., Parnerkar, S. and Kore, K.B. (2012) Effect of feeding bypass nutrients to growing buffalo heifers under field conditions. Livestock Research for Rural Development, 24(2): 39.

11. Movaliya, J.K. (2012) Effect of rumen bypass methionone and lysine supplementation on performance of Jaffrabadi heifers. A M.V.Sc. thesis submitted to Junagadh Agricultural University, Junagadh, India.

12. Odedra, M.D. (2013) Nutritional management by feeding protected lysine and methionine on growth, hematological and hormonal profile of jaffrabadi buffalo heifers. A Ph.D. thesis submitted to Junagadh Agricultural University, Junagadh, India.

13. Dahiya, S.S., Singh, Pawan., Lailer, P.C. and lal, D. (2010) Growth and Nutrient utilization in male Buffalo calves fed limiting amino acids rich supplements. Procceding of international buffalo conference volume-II, 1 to 4 th february 2010, New Delhi.

14. Savsani, H.H. (2012) Effect of feeding varying levels of bypass fat on lactating Jaffrabadi buffaloes. A Ph.D. thesis submitted to Junagadh Agricultural University, Junagadh, India.

15. Gurung, K., Parnerkar, S., Patel, G.R. and Kumar, D. (2009) Effect of feeding bypass protein on growth and feed intake in buffalo heifer calves under field condition. In: Proceedings of Animal Nutrition Association World Conference, 14-17 Feb. 2009, New Delhi India, p.66.

16. Patel, V.R., Gupta, R.S. and Jani, V.R. (2009) Effect of feeding bypass protein on growth and feed intake in buffalo heifer calves under field condition. In: Proceedings of animal nutrition association world conference, 14-17 Feb. 2009, New Delhi Inida. p. 25.

17. Thakur, S.S. and Shelke, S.K. (2009) Growth performance and nutrient utilization of Murrah buffalo calves fed ration supplemented with bypass fat prepared from soybean acid oil. Indian J. of Anim. Sci., 79(12):1238-1241.

18. Mandal, G.P., Kurar, C.K. and Neela, K. (2002) Effect of methionine and lysine supplementation on dry matter intake, nutrition utilization and growth in buffalo calves. Anim. Nutrition and Feed Technology 2(1): 39-47.

19. Brishketu, K. and Thakur, S.S. (2007) Effect of supplementing bypass fat on the performance of buffalo calves. Indian J. of Anim. Nutrition, 24(4): 233-236.

20. Jat, H.R., Chaudhary, J.L. and Bugalia, H.L. (2005) Effect of feeding cottonseed on the body measurements and feed conversion efficiency in growing buffalo heifers. Indian J. of Dairy Sci., 58(3): 198-200.

21. Joshi, V.D., Wankhede, S.M. and Kalbande, V.H. (2005) Effect of feeding bypass protein with urea treated wheat straw on performance of crossbreds (Holstein Friesian X Deoni) calves. Anim. Nutrition Feed Technology, 5(2): 131139. 